\title{
MUHAMMAD SAW PADA PERIODE MEKAH
}

\author{
Heri Firmansyah*
}

\begin{abstract}
ABSTRAK
Dakwah Rasulullah saw., pada periode Mekah merupakan tonggak sejarah bagi penyebaran Islam di selurub Jazirah Arab dan daerab lainnya. Meskipun pada periode ini Islam belum begitu menyebar, namun penanaman akidah dan karakteristik yang kokoh terhadap para sahabat, plus ketabahan dan kesabaran dalam menghadapi tekanan dan ancaman dari kaum kafir Quraisy yang begitu dahsyat bisa dihadapi dan diambil hikmahnya secara baik, menjadikan komunitas Muslim periode awal ini dirasa mampu dan layak. dalam menyongsong sebuah peradaban baru di permukaan bumi. Makalah ini menjelaskan tentang sejarah Rasulullah saw pada periode Mekah dengan tinjanan dari berbagai aspeknya, seperti ekonomi dan perdagangan, sosial kemasyarakatan, kegamaan dan bukum.
\end{abstract}

\section{Kata Kunci: Muhammad, Mekah, Periode Mekah}

\section{Pendahuluan}

Kota Mekah merupakan kota besar yang sangat penting dan terkenal di antara kota-kota di negeri Arab, baik karena tradisinya maupun karena letak keberadaannya. Mekah merupakan tempat stategis karena merupakan jalur perdagangan yang ada di jazirah Arab, menghubungkan Yaman di Selatan dan Syiria di Utara. (Abdurrahman: 1998). Terlebih dengan adanya ka'bah yang menjadi sentral kegiatan keagamaan di kawasan jazirah Arab.

Kota ini tidak dapat dilepaskan dari sejarah Peradaban Islam, karena dari sinilah muncul dan berkembangnya eksistensi Islam ke seluruh pelosok negeri. Rasulullah SAW lahir di kota Mekah dan berusaha untuk membangun fondasi ketauhidan manusia dari kota tersebut. Alquran juga untuk pertama kali dan beberapa masa berikutnya diturunkan di kota Mekah yang berfungsi sebagai way of the life bagi seluruh umat manusia jika ingin hidup dalam rahmatan lil a'lamin. Rasanya janggal sekali jika keberadaan kota Mekah dan

* Penulis adalah dosen Universitas Islam Negeri Medan, Email: herifirmansyah@uinsu.ac.id 
perjuangan Rasulullah SAW dalam mengislamkan penduduknya keluar dari pembahasan sejarah peradaban Islam.

Karena itulah, sebagai kajian pembuka bagi pembahasanpembahasan selanjutnya, Makalah ini berusaha untuk mengungkapkan beberapa dimensi kehidupan yang berkaitan tentang kota Mekah pada periode Rasulullah SAW. Di mana pembahasannya di mulai dengan pemaparan mengenai kondisi Arabiah Pra-Islam, lalu dilanjutkan pada pembahasan yang lebih spesifik lagi mengenai kota Mekah Pra-Islam dan terakhir tinjaun berbagai aspek tentang kota Mekah setelah keberadaan Rasulullah SAW dan penyebaran dakwahnya untuk menyeru kepada manusia kepada ketauhidan Allah swt.

\section{Sekilas Tentang Arabiah Pra-Islam}

Bila dilihat dari asal-usul keturunan, penduduk jazirah Arab dapat dibagi menjadi dua golongan besar, yaitu: Qabtaniyyun (keturunan Qahtan) dan Adnaniyyun (keturunan Ismail bin Ibrahim). Pada mulanya bagian utara jazirah Arab diduduki oleh golongan Adnaniyyun dan wilayah selatan di huni oleh golongan Qabtaniyyun. Akan tetapi lama kelamaan kedua golongan tersebut membaur karena perpindahan dari utara ke selatan atau sebaliknya (Philip: 1970).

Ada perbedaan yang sungguh mencolok dalam bidang-bidang tertentu yang terdapat pada masyarakat Arabia dengan masyarakatmasyarakat di sekitarnya. Mayoritas masyarakat selain Arabia sudah menganut monotheisme sementara masyarakat Arabia masih menganut polytheisme, masyarkat lain sudah berubah menjadi masyarakat agrikultural sementara Arabia adalah masyarakat pengembala, masyarakat lain sudah berubah menjadi masyarakat perkotaan sementara Arabia adalah daerah perkemahan (M. Lapidus 1993).

Hal ini dapat dijelaskan bahwa memang terjadi keterasingan masyarakat Arabia dari masyarakat imperium pada masanya, meski mereka tentu saja tidak terlepas dari pengaruh imperialis yang berkembang pada masa itu. Memang tidak ada batasan yang jelas antara wilayah Arabia yang tidak berada di bawah sebuah imperium dengan wilayah lain yang memang berada di bawah kekuasaan sebuah imperium yang pada saat itu berada di Timur Tengah.

Arabia dihubungkan dengan kultur-kultur lain oleh para propogandis keliling yang juga adalah para pedagang. Para propogandis ini membawa ajaran monotheisme ke dalam masyarakat Arabia. Selain itu juga mempengaruhi pandangan mereka terhadap kebutuhan barangbarang mewah yang telah dikenal pada masyarakat yang relatif lebih 
maju dari mereka, seperti tekstil, anggur, perhiasan dan berbagai macam benda lain.

Perdaban Timur Tengah ini mulai merembes ke dalam masyarakat Arabia. Tampaknya pola seperti ini sangat umum diketemukan dalam masyarakat yang berada di pinggiran sebuah imperium. Hubungan ini saling menguntungkan secara sadar ataupun tidak sadar. Bagi sebuah imperium mereka merupakan masyarakat yang harus ditaklukkan untuk berada di bawah kekuasan politik, meskipun hingga Muhammad saw terlahir, ternyata tidak ada imperium yang mengusai penuh Arabia secara keseluruhan (M. Lapidus 1993).

Tapi disamping itu, ternyata perembesan ini juga membawa stratifikasi sosial yang sebelumnya relatif tidak dikenal oleh masyarakat Arabia. Seperti keinginan untuk mempunyai harta yang lebih banyak dibanding dengan orang lain tumbuh pada masyarakat ini, meski tentu saja hal itu merupakan suatu kecenderungan alamiah manusia.

\section{Sekilas kota Mekah Pra-Islam}

Mekah juga dikenali sebagai Bakkah dan terletak di daerah Hijaz. Ia dipercayai didirikan dalam pertengahan kurun ke-5 SM. Mulamulanya, suku Jurhum menguasainya kemudian suku Khuzaah datang dan menaklukinya dan akhirnya suku Quraisy mengusainya. Sejarah kota Mekah ini bermula dengan peristiwa Nabi Ibrahim a.s. meninggalkan isterinya dan puteranya di lembah yang keringkerontang. Beliau merupakan bangsa Kaldani (di Iraq) dan bertutur dalam Bahasa Ibrani (Hebrew). Kota Mekah ini juga dikenali sebagai Jantung Hati Semenanjung Tanah Arab, mengindikasikan bahwa ia merupakan kota terpenting di Arab (Haikal 1990).

Ada beberapa ciri yang dapat dilekatkan terhadap kota Mekah pra-Islam (website www.geocities.com):

1. Kedudukannya yang Strategis. Walaupun ia dikelilingi oleh bentangan gunung, namun masih terdapat jalan-jalan keluar menuju ke kawasan-kawasan utama di Yaman (Selatan), Palestina dan Syam (Utara) dan Pelabuhan Jeddah (Barat). Kedudukan Mekah berada di tengah-tengah perjalanan ke wilayah-wilayah ini. Ia seolah-olah menjadi sendi perhubungan di antara kawasan-kawasan utama ini. Hal ini menyebabkan ia sering dikunjungi oleh pedagang-pedagang Arab baik dari Utara atau dari Selatan.

2. Ekonomi yang kuat. Mekah merupakan pusat perdagangan di kawasan tengah yang bertaraf antarabangsa. Sebabnya, ia mempunyai persediaan air dari Telaga Zam-zam yang terkenal. Telaga tersebut sebelumnya dikuasai oleh suku Khuza'ah yang kemudian dikuasai oleh 
kabilah Quraisy. Terdapat satu Majlis Siqayah yang berkuasa penuh atas otoritas zamzam, diketuai oleh Abdul Mutalib yang bertugas untuk memberikan air kepada pengunjung-pengunjung Haji. Selain itu, kedudukannya yang strategis juga menjadikannya objek vital bagi berbagai kafilah perdagangan dari Utara ke Selatan. Selain itu, kehandalan kabilah Quraisy sendiri dalam bidang perniagaan juga memperkokoh ekonomi di Mekah.

3. Institusi Sosial. Qusai Bin Kilab telah membentuk Dewan Nadwah yang menjadi tempat bermusyawarah bagi para pemimpinpemimpin Mekah mengenai masalah-masalah yang mereka hadapi. Keberadaannya dapat mempersatukan masyarakat Quraisy yang telah lama terpecah belah kepada satu kabilah yang besar dan mulia. Semasa pemerintahan Abdul Manaf pula, 15 buah majlis dibentuk di bawah Darun Nadwah ini yang berfungsi untuk menjamin keamanan kota Mekah dan melindungi jemaah Haji. Di antaranya ialah Majlis Siqayah (penyediaan air), Majlis Rifadah (penyediaan makanan), Majlis Sidanah (urusan ka'bah), Majlis Asynaq (mahkamah) dan sebagainya. Hal yang tidak kalah pentingnnya adalah Mekah tidak dikuasai oleh seorang raja pun sehingga terbebas dari pengaruh asing.

4. Pasukan atau Tentara. Majlis Unnah (urusan perang) berada di bawah Dewan Darun Nadwah dan bertanggungjawab penuh mengenai ketenteraan serta menyiapkan senjata perang. Jabatan ini dipegang oleh Bani Makhzum. Kewujudan majlis ini menjadikan Mekah dapat mempertahankan kedaulatan sepanjang masa walaupun ketika itu Roma dan Parsia begitu giat melakukan usaha untuk menguasai Semenanjung Tanah Arab. Di Mekah, semua lelaki dijadikan tentera.

5. Agama. Pada permulaan, agama yang dianuti oleh masyarakat Mekah merupakan agama Allah (kemudiannya digelar Hanif). Agama ini dibawa oleh Nabi Ibrahim a.s.. Beliau menyeru masyarakat supaya menganuti-Nya dan mengerjakan Haji. Ka'bah telah didirikan atas perintah Allah. Ketika suku Khuzaah yang berasal dari Yaman mengambilalih pemerintahan Mekah, agama penyembahan berhala diperkenalkan. Buktinya, di sekitar Kaabah saja terdapat 360 berhala. Berhala-berhala ini kekal sehinggalah dihancurkan oleh umat Islam pada tahun 8 Hijrah. Selain itu, terdapat juga agama Yahudi, majusi dan sebagianya.

\section{Prasarana}

Di Mekah, terdapat Pasar Ukadz (Suq-Ukaz) yang terkenal dengan kegiatan pesta-pesta perdagangan dan kesusasteraannya. Selain itu, terdapat juga Pasar Zul Majaz dan al-Majinah yang mempunyai fungsi yang sama. Majlis Siqayah dan Majlis Rifadah juga dibentuk, 
yang bertugas memberikan air dan makanan secara gratis kepada para pengunjung. Selain itu, Ka'bah yang telah dibangun di tengah kota Mekah juga menjadi tempat tumpuan bangsa Arab. Ada sebuah peraturan tidak tertulis bahwa di sekitar Kabah merupakan kawasan haram perang. Bangunan ini telah menjadi pusat ibadat dan pusat kebudayaan bagi mereka.

\section{Muhammad Pada Periode Mekah: Tinjauan Terhadap Berbagai Aspek}

\section{Aspek Ekonomi dan Perdagangan}

Hukum ekonomi dan keuangan menurut ajaran Islam (alAbkam al-Iqtishadiyah wa-Almaliyah) mempunyai bentuk yang sangat bervariasi. Keanekaragaman itu terjadi karena bervariasinya kultur serta pengetahuan yang melatarbelakangi pikiran penulisnya. Namun demikian, secara umum dapat ditegaskan bahwa terminologi al-Abkam al-Iqtishadiyah wa-Almaliyah dipakai untuk menunjuk kepada pengertian hukum (tatanan) yang mengatur sistem ekonomi dan keuangan berkenaan dengan upaya manusia mencukupi kebutuhan, meningkatkan taraf hidup, dan mewujudkan kesejahteraan, baik secara individu maupun secara kolektif.

Dalam periode Mekah umat Islam telah mengenal aktifitas ekonomi dengan bentuknya yang masih sederhana, seperti menggembala binatang ternak, membuat alat rumah tangga atau perang, menjadi buruh kasar, atau budak. Sementara golongan menengah keatas berdagang. Mereka mengenal aktivitas kewirausahaan (wnw.badilag.net). Semisal Usman bin Affan dan Abu Bakr. Nabi Muhammad SAW sendiri pada masa mudanya bekerja sebagai pengembala domba dan seorang pengusaha yang menjalankan bisnis Khadijah yang kelak menjadi isterinya.

Namun memang, Kritikan-kritikan tajam Nabi SAW dalam sektor perdagangan (seperti masalah riba, penumpukan kekayaan atau monopoli, dan lain-lain) terjadi pada periode Madinah. Hal ini tampak berkaitan erat dengan kuatnya kaum Yahudi Madinah sebagai pemeran penting di lapangan perdagangan. Sementara itu, kaum petani dari kalangan Muhajirin dan Anshar sering dirugikan dengan fluktuasi harga yang diciptakan oleh orang-orang tertentu dalam sistem pasar.

Kota Mekah ketika itu merupakan pusat perdagangan, sebagai penghubung jalur perekonomian Samudera Hindia (wilayah timur) dengan Laut Tengah (wilayah barat). Pada pertengahan kedua dari abad ke-enam Masehi, jalan dagang Timur-Barat berpindah dari Teluk 
Persia-Euphrat di Utara dan Laut Merah-Perlembahan Neil di Selatan, ke Yaman-Hijaz-Syria. Peperangan yang senantiasa terjadi antara Byzantin dan Persia membuat jalan Utara tak selamat dan tak menguntungkan bagi dagang. Mesir, mungkin juga sebagai akibat dari peprangan Byzantin dan Persia, berada dalam kekacauan yang mengakibatkan perjalanan dagang melalui perlembahan nil tidak menguntungkan pula.

Dengan berpindahnya perjalanan dagang Timur-Barat ke Semenanjung Arabia, Mekah menjadi kota dagang karena letaknya yang berada strategis dipertengahan jalur dagang tersebut. Pedagangpedagangnya pergi ke Selatan membeli barang-barang yang datang dari Timur, yang kemudian mereka bawa ke Utara untuk di jual di Syria (Hitti 1970). Dari dagang transit ini, Mekah menjadi kaya. Perdagangan di kota ini dipegang oleh suku quraisy dan sebagai orang-orang yang berada dan berpengaruh dalam masyarakat pemerintahan Mekah juga terletak di tangan mereka.

Kekuasaan kota Mekah sebenarnya terletak di tangan kaum pedagang tinggi. Kaum pedagang tinggi ini, untuk menjaga kepentingan - kepetingan mereka mempunyai perasaan dan solidaritas kuat yang kelihatan efeknya dalam perlawanan mereka terhadap Nabi Muhammad saw, sehingga beliau dan pengikut-pengikutnya terpaksa meninggalkan Mekah untuk pergi ke Yasrib. Sebagaimana diketahui nabi bukanlah termasuk golongan yang kaya bahkan termasuk dari kalangan Quraisy yang keadaan ekonominya sederhana sekali, sehingga dia terpaksa mengembalakan kambing guna membantu ekonomi pamannya, Abu Thalib. Maka sepeninggal isterinya yang merupakan bagian dari pebisnis utama kota Mekah, pendukung dan solidaritas dari kaum pedagang tinggi pun melemah. Inilah di antara faktor yang menyebabkan hijrahnya rasul ke Yasrib.

Dari sini dapat dinyatakan bahwa, pada periode awal kekuasaan dan imperium ekonomi di kota Mekah tidak dapat dikuasai oleh kaum Muslimin karena masih sedikit dan lemahnya mereka saat itu. Hal ini terutama disebabkan sebagian besar pengikut Rasulullah saw adalah berasal dari golongan rendah, semisal budak dan buruh kasar yang tidak memiliki pengaruh besar dalam bidang ekonomi di kota Mekah. Sedangkan kebanyakan aristokrat ekonomi kota Mekah semisal Abu Sufyan dan Abu Jahl yang memiliki jaringan bisnis kuat, sangat membenci dan menentang dakwah yang dilakukan oleh Rasulullah saw.

Pelemahan ekonomi terhadap umat Islam di kota Mekah menampakkan efeknya yang dahsyat saat terjadinya pemboikotan total 
terhadap keluarga Bani Hasyim dan Bani Abdul Muthalib oleh seluruh seluruh suku yang ada di Mekah untuk tidak saling mengawinkan dan tidak berjual beli apapun, sehingga pada masa-masa pemboikotan tersebut kaum muslimin berada pada titik nadir ekonomi yang teramat lemah (Haikal 1990).

\section{Aspek Sosial-Kemasyarakatan}

\section{A. Sistem Keluarga Masyarakat Mekah}

Muhammad datang dan ditugaskan untuk menyeru masyarakat yang pada umumnya mengenal sistem keluarga patriarkhal yang sungguh kental, keluarga mereka terdiri dari ayah, ibu dan anakanaknya. Keluarga-keluarga ini bersatu untuk menghasilkan kerjasama yang saling menguntungkan yang biasanya berdasarkan nasab yang kemudian disebut dengan klan. Masyarakat Mekah lebih tertarik dengan sistem kolektifitas dalam beberapa hal termasuk keamanan pribadi. Mereka relatif tidak mengenal konsep pribadi. Mereka sangat tergantung kepada klan masing-masing. Seorang individu bertanggung jawab atas klannya, penganiayaan terhadap seorang anggota klan berarti juga penganiayaan terhadap klan. Tidak ada balas dendam pribadi pada umumnya, tetapi pembalasan tindak aniaya dilakukan oleh klan. Seorang yang tidak bernaung di bawah sebuah klan tidak mendapat tempat di Mekah.

Setiap klan biasanya dipimpin oleh seorang syaikh yang dianggap paling bijak, kaya dan banyak berderma. Biasanya setiap anggota klan yang ingin bertindak dalam beberapa bidang tertentu meminta saran pemimpin klan. Dari beberapa pernyataan ahli-ahli sejarah, kami berpendapat bahwa memang orang-orang Arab adalah orang yang mempunyai kesetiaan lebih tinggi kepada pemimpinnya dibanding dengan orang-orang selain mereka pada saat itu (Asghar 1980).

Hukum tentang status keluarga dan pribadi tampaknya sudah mengakar kuat dalam masyarakat Mekah, yang berasal dari sistem Arab purba (Schacht 1971). Sistem keluarga yang ada pada masyarakat Arab hanya berlaku untuk anggota klan. Hingga diantara klan-klan yang terjadi perselisihan biasanya diangkat seorang hakim. Klan yang bersengketa tersebut memberikan jaminan untuk menaati keputusan sang hakim, baik dengan jaminan materi ataupun dengan janji (Dahlan, Ensiklopedi Hukum Islam, 1991)

Rasulullah saw. tidak bisa berbuat banyak untuk merubah keadaan ini ketika beliau berada di Mekah, meski tentu saja dalam kalangan intern masyarakat muslim yang pada saat itu masih sangat 
sedikit sekali, prilaku-prilaku yang tidak sesuai dengan ajaran Islam telah mulai ditinggalkan.

\section{B. Tribalisme dan Sistem Kepemimpinan}

Tribalisme atau paham kesukuan berkembang sangat pesat di Jazirah Arab, jauh sebelum kedatangan Islam. Hal ini dapat dipahami karena sebagian besar penduduknya adalah masyarakat penggembala (pastoral). Mereka berpindah dari satu tempat ke tempat lainnya sesuai dengan musim yang terjadi guna mencari tanah yang subur dan daerah yang sesuai untuk ditinggali. Hal ini dilakukan guna memenuhi kebutuhan hidup mereka dikarenakan satu lahan atau daerah tidaklah cukup untuk memenuhi kebutuhan dan menghadapi empat musim yang berbeda.

Dalam masyarakat Arab, paham tribalisme ini berkaitan erat dengan konsep Asabiah atau solidaritas sosial. Solidaritas sosial sangat berpengaruh dan mengakar pada masyarakat pengembara, karena mereka memiliki corak cara hidup yang khas. Disebabkan oleh kebutuhan hidup, mereka harus saling membantu yang terus menerus. Lebih-lebih kemiskinan padang pasir mempengaruhi mereka untuk tidak terikat kepada tanah kelahiran, sehingga semua negeri atau daerah sama dalam pandangan mereka dan tidak ada yang istimewa (Issawi 1976).

Orang-orang yang berpindah-pindah ini hidup dalam ikatan kelompok kekerabatan, keluarga patriarkal yang terdiri seorang ayah, anak laki-lakinya, dan keluarga mereka. Keluarga - keluarga ini selanjutnya berkelompok menjadi sebuah klan yang terdiri dari ratusan rumah tenda, yang mana secara bersama-sama mereka pindah, memiliki padang rumput, dan bertempur sebagai satu kesatuan di medan perang. Secara fundamental masing-masing klan merupakan sebuah kesatuan yang mandiri (Lapidus 1999).

Seluruh kesetian terserap oleh kelompok yang bertindak sebagai sebuah kolektifitas untuk mempertahankan individu warganya dan untuk menghadapi tanggung jawab bersama. Jika seorang warga teraniaya, maka klan menuntut balas atas penganiayaan tersebut. Jika seseorang melakukan penganiayaan, maka hal itu menjadi tanggung jawab klan. Hal ini tampak jelas dengan syair mereka "tolonglah saudaramu baik dizolimi atau menzolimi”. Sebagai solidaritas kelompok yang disebut asabiyah tersebut, klan badui atau keumuman masyarakat Arab memandang dirinya sebuah kebijakan yang penuh dan menganggap tidak ada otoritas eksternal. Seorang klan dipimpin oleh seorang syaikh yang biasanya dipilih oleh warga klan yang tua-tua dari 
salah satu keluarga berpengaruh dan ia senantiasa bertindak setelah meminta saran-saran mereka (Lapidus 1999).

Kehidupan dipadang pasir memerlukan perasaaan kesukuaan, karena sukuisme itulah yang melindungi keluarga dan warga suatu suku. Hal ini disebabkan terutama karena di padang pasir tidak ada pemerintah atau suatu badan resmi, yang dapat melindungi rakyat atau warga negaranya dari penganiayaan dan tindakan sewenang-wenang dari siapa saja. Maka kabilah atau suku itulah yang merupakan suatu kesatuan yang mengikat warganya dengan ikatan darah (keturunan) atau ikatan kesukuaan. Kabilah atau suku itulah yang berkewajiban melindungi warganya, dan melindungi orang-orang yang menggabungkan diri atau meminta perlindungan kepadanya (Sya'labi 2000).

Struktur serupa ini pula yang yang terdapat dikota Mekah yang didomisili oleh suku Quraisy yang terdiri dari beberapa klan atau keluarga. Namun di Mekah memiliki sistem atau struktur pemerintahan yang lebih spesifik karena distribusi kekuasaan yang dibagi secara merata kepada bangsawan Mekah yang mewakili kelompoknya atau klannya. Kekuasaan dipegang secara kolektif oleh pemuka-pemuka Mekah yang terhimpun didalam sebuah dewan yang disebut Dar anNadwah (Azizi 2000).

Qushai adalah orang pertama dari bani Ka'ab bin Lu'ay ( Quraisy ) yang berhasil meraih kekuasaan dan kepatuhan dari kaumnya, setelah merebut kekuasaan tersebut dari bani Khuza'ah. Semua urusan penduduk Mekkah dibawah kendalinya tanpa ada campur tangan orang lain. Urusan tersebut berupa pengelolaan ka'bah (hijabah), penyediaan air minum dan makanan (siqayah dan rifadah) bagi jamaat dari manamana yang berziarah ke ka'bah, nadwah (penyelenggaraan musyawarah) dan liwa (urusan pertahanan atau perang) (Al-Husaini 1995).

Karena pengaruh dari rasa sukuisme yang kuat dan ingin memperoleh gengsi kepemimpinan, maka acapkali terjadi peperangan antara suatu suku dengan suku lainnya atau antara satu kelompok keluarga dengan keluarga lainnya. Permasalahan ini bisa ditimbulkan hanya berdasarkan salah seorang saja dari anggota suku yang bertikai yang berkembang menjadi pertikaian masal diantara suku dan keluarga tersebut. Peperangan-peperangan ini kadangkala dapat terus berlanjut hingga sampai beberapa keturunan.

Sebagai contohnya adalah keluarga Bani Hasyim dan Bani Umayyah, yang sebenarnya masih berada dalam satu keturunan yakni Abd Manaf. Seperti yang terlihat dalam bagan berikut: 


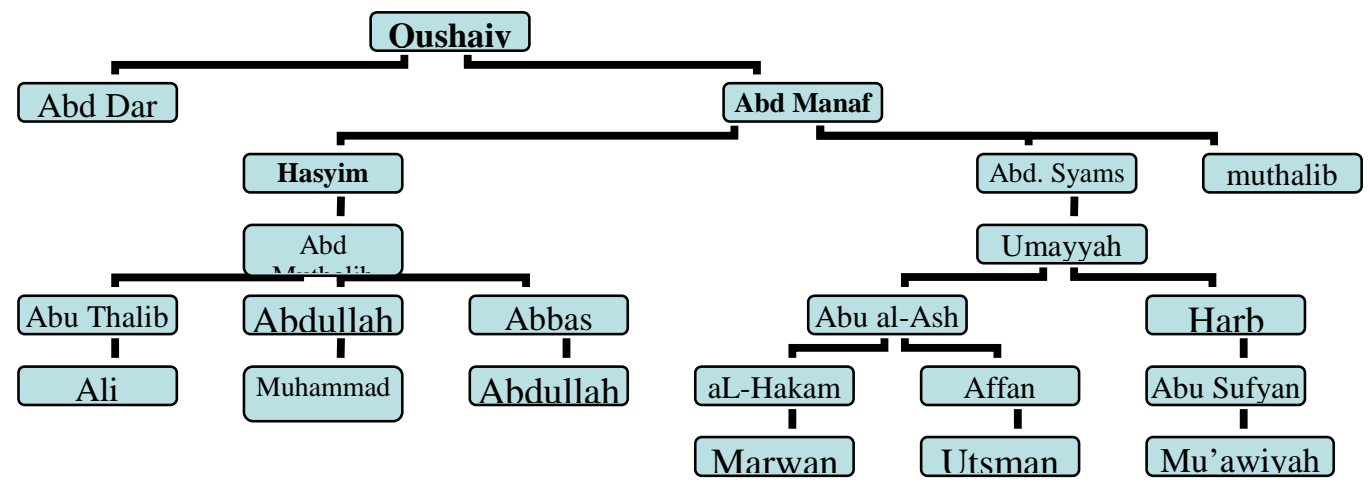

Mereka terlibat perselisihan panjang mengenai hak siqayah dan rifadah. Karena penguasaan akan dua hal yang penting ini Hasyim memperoleh kedudukan terhormat dan mulia dikalangan bangsa Arab. Ditambah lagi dengan catatan bahwa ia adalah orang pertama yang memulai tradisi perjalanan musim dingin dan musim panas. Sehingga keluarga mereka memperoleh predikat al-Faidl atau yang memiliki keutamaan. Demikian pula dengan anaknya Bani Abdul Muthalib yang melakukan untuk pertama kalinya penggalian sumur zam-zam yang telah lama terkubur (al-Husaini 1995).

Hal ini menimbulkan kecemburuan dikalangan Bani Umayyah yang merupakan keponakan Hasyim, karena mereka tidak mendapatkan kedudukan dan kehormatan yang didapatkan Bani Hasyim, padahal mereka sama-sama merupakan keturunan Abd Manaf. Mereka merasa hak-haknya dikebiri oleh Hasyim dan keturunannya dengan tidak memperoleh bagian dalam pengurusan Siqayah dan rifadah. Padahal hak itu diperoleh melalui perjuangan bersama yang direbut dari keluarga Bani Abd Dar, antara Hasyim dan Bapak mereka Abd Syams. Pertikaian ini menyebabkan Umayyah hijrah ke Syam dan di sana menjalankan bisnis perdagangan (Penyusun, Ensiklopedi Islam, 2001). Oleh sebab itulah nantinya kita kenal, banyak dari keluarga Bani Umayyah yang menjadi pengusaha sukses, sedangkan Bani Hasyim menguasai pengaruh kekuasaan dan politik di kota Mekah.

Perselisihan ini terus berlanjut sampai kedatangan Islam. Muhammad bin Abdullah sebagai Rasulullah pembawa risalah Islam, dianggap sebagai kemenangan Bani Hasyim. Mereka mendapatkan dominasi politik dan pengaruh yang besar atas bangsa Arab. Karena itu banyak dari anggota Bani Umayyah yang menjadi penentang utama dakwah Rasulullah SAW. Diantaranya adalah Abu Sufyan ayah Mu'awiyah, seorang bangsawan Quraisy yang disegani dan dihormati. Ia 
banyak melakukan penentangan dan penindasan terhadap Rasulullah dan para pengikutnya. Ia juga salah satu pemimpin pasukan Qurasiy dalam memerangi Islam di Perang Badr. Begitu juga dengan anakanaknya, Mu'awiyah dan Yazid. Mereka adalah orang-orang yang masuk Islam dalam keadaan terpaksa dan memperoleh pengampunan pada peristiwa Fathul Mekah.

Meskipun tampaknya masih perlu pengkajian yang lebih dalam mengenai kebenaran akan kaitan antara kontinuitas pertikaian yang terjadi antara Bani Hasyim dan Bani Umayyah dengan banyaknya keterlibatan keluarga Bani Umayyah dalam usaha penolakan terhadap dakwah Rasulullah saw di Mekah, ini dikarenakan terdapat juga keluarga Bani Umayyah yang mendukung Rasulullah saw semisal Usman, dan terdapat anggota Bani Hasyim dan Bani Abdul Muthalib yang menentangnya semisal Abu Lahab, namun hampir dapat dipastikan bahwa ikatan kesukuan dalam anggota keluarga amat tertancap dengan kuat pada periode awal dakwah Rasulullah saw di Mekah. Persaudaran kesukuan dan ikatan darah semacam inilah yang berusaha untuk dirubah oleh Rasulullah saw dengan menekankan bahwa persaudaraan dan kepemimpinan adalah ditentukan atas akidah islamiyah dan siapa yang terbaik dari sisi keimanan, keamanahan dan kesanggupan, bukan berdasarkan pada ikatan darah dan kesukuan.

Tampaknya hal ini teramat sulit dirubah oleh Rasulullah saw bukan hanya pada periode awal dakwahnya di Mekah namun pada perjalanan agama Islam berikutnya. Meskipun Akidah Islamiyah diakui dan telah tertancap dalam setiap dada orang mukmin sebagai pengikat erat setiap Muslim, namun karena perebutan kekuasaan dan kepemimpinan rela untuk menumpas saudara mukmin lainnya yang berbeda klan dan kesukuan dari mereka, seperti yang ditunjukkan dari pendirian dinasti Umayyah, Abbasyiah dan dinasti-dinasti lainnya.

\section{Kedudukan Wanita}

Pada umumnya, bukan hanya di Mekah, wanita tidak diberi

peran signifikan terhadap kehidupan bermasyarakat. Mereka diperlakukan tidak seperti wanita pada masa modern ini. Tampaknya hal ini merupakan bias dari sistem patriarkhal yang dianut oleh masyarakat Arabia, dalam hal ini masyarakat Mekah (Rachman 2001). Kemungkinan besar, wanita tidak mendapatkan warisan dari ayahnya. Seorang ayah bisa saling bertukar putri dengan ayah lain untuk dinikahi.

Pelecehan terhadap wanita dalam masyarakat Mekah tergambar jelas dalam prilaku sosial, pernikahan, pengontrolan harta dan pembunuhan bayi perempuan. Dalam pernikahan meskipun mereka 
mengenal mahar, tapi ternyata sang ayahlah yang menerima mahar tersebut, juga bukan merupakan adat yang tidak tercela untuk mengawini wanita lalu menceraikannya dan mengawininya kembali dengan semena-semena, atau menikahi wanita sebanyak yang mereka suka (Nashir 1976). Sedangkan dalam pengontrolan harta, wanita sama sekali tidak mempunyai hak. Meskipun harta tersebut merupakan milik pribadi si perempuan. Dehumanisasi perempuan yang paling jelas tergambar dalam pembunuhan bayi perempuan, karena anggapan bahwa mempunyai anak perempuan adalah aib (Esposito 2002).

Namun tampaknya perlakuan dan pembunuhan tersebut seperti yang diungkapkan Esposito dan K. Ali tidaklah berlaku umum bagi setiap wanita di kalangan bangsa Arab, hanya terdapat pada kasus tertentu dan bagi wanita dari kalangan tertentu saja. Kenyataan membuktikan bahwa bangsa Arab terus berkembang biak hingga sampai saat ini mengindikasikan bahwa tidak setiap bayi wanita yang lahir dibunuh, karena tentu saja yang melahirkan bangsa Arab adalah wanita.

Siti Khadijah sendiri yang merupakan isteri Rasulullah saw tidak ada yang menyangkal merupakan seorang bisnisman wanita sukses dan kaya yang membangun raksasa bisnis ekspor-impornya sehingga mendapatkan kedudukan terhormat dikalangan penduduk kota Mekah. dan bahkan mempekerjakan banyak pria untuk menjalankan bisnis perdagangannya, termasuk Rasulullah saw (Brocelman 2000).

Menurut Marshall Hodgson, di samping kondisi-kondisi di atas, ada juga beberapa trend yang berlaku dalam masyarakat wanita Mekah, yakni kebiasaan memakai cadar sebagai simbol dari kehormatan wanita. Beberapa wanita yang tidak bisa diperlakukan seperti wanita lain, atau wanita yang ingin menyatakan dirinya sebagai wanita terhormat biasanya memakai cadar sebagai simbol (Hodgson 1974).

\section{Perbudakan}

Memang ada beberapa trend yang sedang dipraktekkan oleh mayoritas bangsa diseluruh dunia. Selain polygami, mungkin perbudakan adalah hal yang lebih signifikan untuk disebutkan sebagai salah satu ciri peradaban manusia pada masa kuno. Baik di Asia, maupun Eropa perbudakan adalah hal yang sering ditemui.

Dalam masyarakat Mekah, seorang yang tidak mempunyai klan akan dijadikan budak. Klan yang kalah dalam perang juga akan bernasib serupa. Orang-orang yang mempunyai budak berkuasa penuh atas tenaga, hidup dan mati seorang budak (Ali 1998). Budak wanita bisa diajak tidur oleh tuannya, tanpa memperdulikan hak-hak si wanita bahkan ketika ternyata mereka hamil karena hubungan intim tersebut. 
Anak seorang budak secara otomatis menjadi budak yang dimiliki oleh tuan yang memiliki ibu mereka (Sya'labi 1982).

\section{Aspek Keagamaan}

Secara umum daerah Arabiah tak terkecuali kota Mekah bila ditinjau dari nuansa spiritualitasnya terpengaruh oleh berbagai ajaran, diantaranya adalah (mwn.mediaisnet.org):

- animisme, yaitu : kepercayaan setiap benda didiami roh.

- dinamisme, yaitu : kepercayaan pada daya-daya gaib pada benda atau tempat tertentu.

- fetisisme, yaitu : kepercayaan pada jin-jin yang bersifat baik maupun jahat.

- hanifisme, yaitu : tendensi monoteistik yang bersifat asketik.

- serta perbauran komunitas Yahudi dan Kristen yang datang pada abad 1 Masehi. Komunitas Yahudi dan Kristen berdomisili di Medinah.

Sebelum Islam, ada keberagaman kepercayaan yang berkembang ketika itu, ada yang menyembah berhala. Namun kepercayaan yang terkenal adalah penyembahan terhadap berhala (paganisme). Penyembahan terhadap berhala itu sendiri mulanya adalah kebiasaan dari orang-orang yang pergi keluar kota Mekah, mereka selalu membawa batu yang diambil dari sekitar Ka'bah. Mereka mensucikan batu dan menyembahnya di mana mereka berada. Lama kelamaan, dibuatlah patung yang disembah dan mereka berkeliling mengitarinya. Hal ini mereka lakukan karena rasa hormatanya kepada Ka'bah. Akhirnya mereka sendiri memindahkan patung itu disekitar Ka'bah yang berjumlah mencapai 360 buah. Di antara ke-360an berhala itu ada empat buah berhala yang terpenting: (1) Hubal, yang dianggap sebagai Dewa yang terbesar, terbuat dari batu akik warna merah, (2) Lata, Dewa tertua terletak di Thaif, (3) Uzza, terdapat di bawah Hubal dan (4) mant yang terletak di Yasrib.

Nabi sendiri telah menghancurkan berhala-berhala itu dan menganjurkan para sahabat menghancurkannya di mana saja adanya. Kaum Muslimin sudah tidak lagi bicara tentang itu sesudah semua yang berhubungan dengan pengaruh itu dalam sejarah dan lektur dihilangkan. Tetapi apa yang disebutkan dalam Quran dan yang dibawa oleh ahli-ahli sejarah dalam abad kedua Hijrah - sesudah kaum Muslimin tidak lagi akan tergoda karenanya - menunjukkan, bahwa sebelum Islam paganisma dalam bentuknya yang pelbagai macam, mempunyai tempat yang tinggi. 
Di samping itu menunjukkan pula bahwa kekudusan berhalaberhala itu bertingkat-tingkat adanya. Setiap kabilah atau suku mempunyai patung sendiri sebagai pusat penyembahan. Sesembahansesembahan zaman jahiliah inipun berbeda-beda pula antara sebutan shanam (patung), wathan (berhala) dan nushub. Shanam ialah dalam bentuk manusia dibuat dari logam atau kayu, Wathan demikian juga dibuat dari batu, sedang nushub adalah batu karang tanpa suatu bentuk tertentu. Beberapa kabilah melakukan cara-cara ibadahnya sendirisendiri. Mereka beranggapan batu karang itu berasal dari langit meskipun agaknya itu adalah batu kawah atau yang serupa itu.

Di antara berhala-berhala yang baik buatannya agaknya yang berasal dari Yaman. Hal ini tidak mengherankan. Kemajuan peradaban mereka tidak dikenal di Hijaz, Najd atau di Kinda. Sayang sekali, bukubuku tentang berhala ini tidak melukiskan secara terperinci bentukbentuk berhala itu, kecuali tentang Hubal yang dibuat dari batu akik dalam bentuk manusia, dan bahwa lengannya pernah rusak dan oleh orang-orang Quraisy diganti dengan lengan dari emas. Hubal ini ialah dewa orang Arab yang paling besar dan diletakkan dalam Ka'bah di Mekah. Orang-orang dari semua penjuru jazirah datang berziarah ke tempat itu.

Ada pendapat lain juga yang mengatakan bahwa ajaran penyembahan terhadap berhala ini dibawa oleh 'Amar bin Luhay alKhuza'i, orang pertama sekali yang membawa patung ke Ka'bah. Luhay membawa patung itu dari penduduk Syam yang menyembah berhala dan ia menganggap hal itu sebagai sesuatu yang baik dan benar. Sebab menurutnya Syam adalah tempat para Nabi dan Rasul dan tempat turunnya Kitab, maka kemudian ia meminta satu patung untuk dibawa pulang ke Mekah dan diletakkan di Ka'bah patung itu diberi nama Hubal. Luhay sendiri terkenal sebagai orang yang suka melakukan kebaikan dan suka menolong orang lain. Sehingga orang Arab menganggapnya sebagai ulama besar dan wali yang disegani, Dan semua ajaranya diikuti oleh banyak orang. Orang Hijaz juga banyak yang mengikuti ajaran ini Karena mereka manganggap bahwa, orang Arab adalah pengawas Ka'bah dan penduduk tanah suci (Mufrodi 1997).

Tradisi keagamaan bangsa Arab terhadap penyembahan berhala yang diciptakan oleh Luhay ini kemudian menjadi kepercayaan mayoritas kepercayaan orang Arab. Sementara orang mengira apa yang dibuat Luhay adalah sesuatu yang baru dan baik serta tidak merubah ajaran Nabi Ibrahim. Di antara ekspresi dari aktualisasi penyembahan berhala tersebut adalah (Haikal 1990): 
1. Mereka mengelilingi berhala sambil membaca mantra, meminta pertolongan dari segala kesulitan dan berdoa untuk memenuhi segala keinginan mereka.

2. Menunaikan ibadah haji dengan mengelilingi Ka'bah dan berhala sambil menunduk dan sujud dihadapannya tanpa berbusana.

3. Memberikan korban berupa penyembelihan hewan piaraan.

4. Memberi sajian makanan dan minuman yang khusus untuk disuguhkan kepada berhala, sebagai rasa syukur atas keberhasilan panennya.

5. Bernazar untuk menyembelih hewan atau memberikan sajian jika keinginannya terwujud.

Tetapi adapula yang masih menganut agama Masehi dan Yahudi. Agama Masehi ini banyak dianut oleh penduduk yang banyak berasal dari Yaman, Najran dan Syam. Sedangkan agama Yahudi banyak dianut oleh para imigran dari Yasrib. Di samping itu ada pula agama Majusi yang dianut oleh orang Persia.

Hamka menambahkan ada juga yang menganut agama Nabi Ibrahim, yang menurutnya kepercayaan terhadap agama Nabi Ibrahim itu dapat dibagi dua: Pertama, tetap menganut apa yang diterimanya dari Nabi Ibrahim, tidak dirubahnya. Kedua, ajaranya ditambah dengan beberapa tambahan namun ajarannya tetap dinamai juga dengan agama Nabi Ibrahim (Hamka 1987).

Tidak cukup dengan berhala-berhala besar itu saja buat orangorang Arab guna menyampaikan sembahyang dan memberikan kurbankurban, tetapi kebanyakan mereka itu mempunyai pula patung-patung dan berhala-berhala dalam rumah masing-masing. Mereka mengelilingi patungnya itu ketika akan keluar atau sesudah kembali pulang, dan dibawanya pula dalam perjalanan bila patung itu mengijinkan ia bepergian. Semua patung itu, baik yang ada dalam Ka'bah atau yang ada di sekelilingnya, begitu juga yang ada di semua penjuru negeri Arab atau kabilah-kabilah dianggap sebagai perantara antara penganutnya dengan dewa besar. Mereka beranggapan penyembahannya kepada dewa-dewa itu sebagai pendekatan kepada Tuhan dan menyembah kepada Tuhan sudah mereka lupakan karena telah menyembah berhala-berhala itu.

Meskipun Yaman mempunyai peradaban yang paling tinggi di antara seluruh jazirah Arab, yang disebabkan oleh kesuburan negerinya serta pengaturan pengairannya yang baik, namun ia tidak menjadi pusat perhatian negeri-negeri sahara yang terbentang luas itu, juga tidak menjadi pusat keagamaan mereka. Tetapi yang menjadi pusat adalah Mekah dengan Ka'bah sebagai rumah Ismail (Hitti 1970). Ke tempat itu 
orang berkunjung dan ke tempat itu pula orang melepaskan pandang. Bulan-bulan suci sangat dipelihara melebihi tempat lain.

Oleh karena itu, dan sebagai markas perdagangan jazirah Arab yang istimewa karena letaknya yang strategis, Mekah dianggap sebagai ibukota seluruh jazirah. Kemudian takdirpun menghendaki pula ia menjadi tanah kelahiran Nabi Muhammad, dan dengan demikian ia menjadi sasaran pandangan dunia sepanjang zaman. Ka'bah tetap disucikan dan suku Quraisy masih menempati kedudukan yang tinggi, sekalipun mereka semua tetap sebagai orang-orang Badwi yang kasar sejak berabad-abad lamanya.

Salah satu dari tradisi masyarakat Arab yang juga merupakan sikap keberagamaan adalah bila seseorang hendak mengambil sesuatu keputusan, maka ia berlindung dan memohon kepada bantuan mangkuk undian, lalu undian itupun dilakukan. Jika yang keluar adalah yang bertuliskan "ya", maka ia berangkat dan sebaliknya jika yang keluar "tidak", maka keberangkatannya dibatalkan (al-Mubarak 1997).

Selain itu, yang patut kita sebutkan disini adalah bahwa masyarakat Mekah menyepakati diadakannya masa haram, masa ini dikhususkan untuk beribadah tahunan, menziarahi Ka'bah. Hal ini memberikan keuntungan bagi para pedagang Mekah, karena selain menjadi tempat ibadah tahunan, juga menjadi sarana perdagangan. Selain itu ternyata masa haram ini dipergunakan untuk menyelesaikan persengketaan antara klan.

Pada saat kondisi keberagamaan yang seperti itulah kemudian nabi Muhammad muncul dengan membawa sebuah ajaran baru bagi Masyarakat Mekah. Ajaran baru tersebut tentu saja tidak mendapatkan penerimaan yang baik di Mekah. Muhammad harus berjuang ekstra keras untuk mendakwakan ajaran yang beliau emban tersebut. Sala satu faktor mereka berat untuk menganut agama Islam yang dibawa oleh Muhammad, sebab mereka beranggapan bahwa hal itu akan meruntuhkan tradisi-tradisi mereka dan dasar-dasar kehidupan mereka, khususnya dalam bidang keagamaan.

\section{Aspek Intelektual}

Pada waktu Islam diturunkan, bangsa Arab dikenal dengan sebutan "kaum jahili". Kaum Quraisy penduduk Mekah sebagai bangsawan di kalangan bangsa Arab hanya memiliki 17 orang yang pandai tulis baca. Suku Aus dan Khajraz yang merupakan mayoritas dari penduduk Yastrib (Madinah), hanya memiliki 11 orang yang pandai membaca (Amin 1965). Hal ini menyebabkan bangsa Arab sedikit sekali mengenal ilmu pengetahuan dan kepandaian lain. 
Keistimewaan mereka hanyalah ketinggian dalam bidang syair-syair Jahili yang disebarkan secara hafalan. Agama warisan Nabi Ibrahim as dan Nabi Ismail as hanya tinggal bekas-bekasnya yang telah diselewengkan (Susanto 2003).

Pada bidang imu pengetahuan, Rasulullah memberikan perhatiannya yang besar, terutama dalam periode awal peletakkan dasar keimanan dan ketauhidan bagi umat Islam, yakni masyarakat kota Mekah. Hal ini di samping untuk memudahkan beliau dalam membimbing masyarakat keluar dari kebejatan moral sebagaimana misinya untuk membumikan akhlak mulia, juga ajaran Islam sendiri amat menjunjung tinggi kegiatan dan semangat mengembangkan intelektualitas diri, demi untuk kemashlahatan kehidupan manusia.

Dalam hal ini Rasulullah memberikan contoh revolusioner bagaimana seharusnya mengembangkan ilmu. Beliau mendapatkan dan meletakkan hal-hal yang akan menjadi landasan dasar bagi usahanya dalam mengembangkan intelektual umat Islam, di antaranya :

1. Wahyu pertama yang diterima Rasul berbunyi “قرأ "bacalah. Hal ini mendorong orang untuk memperhatikan fenomena alam, mengetahui sunnatullah yang menguasai segala peristiwa alam, dan mengambil kesimpulan tentang hakikat yang terletak di balik kenyataan yang empiris. Perintah ini pada hakikatnya adalah pancangan dan pemberantasan buta huruf, suatu tindakan awal yang membebaskan umat manusia dari ketidaktahuan (Shihab 2006). Membaca dan memahami merupakan pintu bagi pengembangan ilmu. Dengan membaca manusia bisa memahami rangkaian huruf dan lebih dari itu, bisa memahami firman-firman Allah yang tergelar di alam maya ini.

2. Bangsa Arab adalah bangsa yang kuat hafalannya, sedangkan hafalan merupakan salah satu alat untuk pengembangan ilmu. Oleh karena itu, Nabi saw tetap memanfaatkan keistimewaan daya ingat bangsa Arab. Mereka disuruh menghafal Alquran dengan sungguhsungguh sehingga mereka dapat menghafal secara otentik dan utuh. Allah swt memang telah mengungkapkan bahwa Dialah penjaga Alquran, dan salah satu cara dalam penjagaannya adalah dengan banyaknya penghafal Alquran secara utuh pada setiap generasi. Dengan cara ini seandainya ada usaha untuk menghancurkan, Alquran dapat ditulis kembali tanpa ada sedikitpun yang berubah dari aslinya (al-Mubarak 1997).

3. Nabi membuat tradisi baru yaitu dengan mencatat dan menulis pada Sesuatu yang dianggap perlu, dalam hal ini tentu saja pencatatan Alquran. Semua sahabat yang pandai membaca dan 
menulis diangkat menjadi juru tulis untuk mencatat semua wahyu yang turun pada benda-benda yang dapat ditulis seperti kulit, tulang pelepah kurma dan lain-lain. Selain mencatat untuk nabi banyak sahabat yang membuat catatan untuk dirinya sendiri. Di samping itu sahabat juga ada yang mencatat hadis-hadis nabi. Adanya dua sumber ajaran Islam yakni Alquran dan Hadis yang harus ditulis dan dihafal sehingga keorisinalan dan keotentikannya dapat dijaga terus mendorong generasi awal dari kalangan sahabat bersungguhsungguh dalam mementingkan kepentingan baca-tulis. Para tawanan perang Badar, yang mampu tulis baca dapat membebaskan diri dengan mengajarkan sejumlah 10 orang (Hasan 1979).

4. Dengan dorongan dan bimbingan Rasulullah saw telah tumbuh tempat yang dapat dikatakan cikal bakal madrasah atau sekolah pertama Islam sebagai tempat latihan baca-tulis dan juga pengajaran tentang pengetahuan keagamaan. Sekolah tersebut bernama Dar alArqam, bertempat di rumah seorang sahabat yang bernama Arqam. Di sinilah Rasulullah saw membangun tradisi keilmuan masa awal dan membina intelektual para sahabat dalam kaitannya dengan ajaran Islam juga mengenai baca tulis. Lalu tradisi ini dilanjutkan pada periode Madinah dengan membangun kuttab di emperan mesjid Nabawi setelah kehijrahan beliau ke kota tersebut. Kuttab itu terus berlanjut dari generasi ke generasi sehingga pada abad II Hijriah hampir di setiap daerah di dunia Islam memilikinya dan umat Islam menjadi umat yang memasyarakatkan kepandaian baca tulis (yunus 1996). Rasulullah saw juga mengirimkan dua orang sebagai perwakilannya atas permintaan kaum anshor untuk menjadi guru bagi masyarakat kota Yastrib (Madinah) sebelum kedatangan beliau ke tempat tersebut yakni, Mus'ab bin Umayr dan Ibn Ummi Maktum. Mereka mengajarkan tentang ajaran Islam beserta Alquran dari rumah ke rumah para pengikut Rasulullah saw yang nantinya akan menjadi pendukung setianya di kota Madinah (Chaudri 1999).

5. Alquran merupakan sumber inti ilmu pengetahuan, karena Alquran memuat: 1). Kisah umat-umat terdahulu. 2). Segala macam hukum dasar: Perkawinan, perdara, pidana, perniagaan, juga berbagai perundang-undangan seperti politik, ekonomi dan sosial, meskipun masih dalam bentuknya yang umum dan tidak mendetail. 3). Sifatsifat Allah swt seperti I'lm, Qudrah, Iradah, Wahdaniyyah dan lain sebagainya. Dan jalan untuk mengetahui sifat-sifat-Nya tersebut adalah dengan mempergunakan cara mengaja manusia untuk memperhatikan, menelaah dan mempelajari alam semesta seperti 
banyak ayat yang tersebar di dalam Alquran, salah satunya adalah surah al-Imran ayat 191 yang memerintahkan manusia untuk mengkaji tentang kejadian langit dan bumi dan peredaran waktu siang dan malam.

Dengan landasan-landasan ini, Rasul mulai membangun jiwa umat Islam. Rasulullah saw membimbing terlebih dahulu para sahabat untuk beriman dan berilmu. Rasul mengajak sahabat-sahabat untuk mempercayai Allah Yang Maha Esa, tidak syirik, berakhlak mulia, dapat dipercaya, jujur dan sekaligus berilmu. Rasul selalalu mengajak dan membimbing para sahabat hingga mendapatkan pemahaman yang benar pada ajaran Islam, karena beliau senantiasa menyampaikan dan menjelaskan setiap wahyu yang diturunkan Allah swt kepada beliau.

Mula-mula tempat pertemuan majlis ilmu antara Rasul dan sahabatnya berada di rumah Rasul sendiri, lalu kemudian dengan berbagai pertimbangan tempatnya pun dipindahkan di rumah salah seorang sahabat bernama Arqam di luar kota Mekah, yang disebut Dar al-Arqam. Di sinilah Rasulullah saw berdakwah, membimbing dan membina umat Islam awal, sehingga -seperti yang telah dijelaskantempat tersebut dapat dianggap sebagai Lembaga Pendidikan Pertama yang didirikan Rasulullah saw.

Pada tempat itu Rasul mengajak para sahabat untuk menghafal, memahami dan mengamalkan isi ayat-ayat Alquran yang sudah turun, selanjutnya menyuruh sahabat yang pandai menulis untuk menuliskannya dalam berbagai bahan material. Tentang kepandaian menulis ayat-ayat Alquran, Ahmad Amin menyatakan Rasul menyuruh para sahabat untuk membuat huruf. Menurutnya, dalam salah satu riwayat, Ali bin Abi Thalib disuruh membuat huruf dengan mencontoh dari huruf bangsa Himyar. Mulai usaha itu umat Islam sudah mengarah kepada kepandaian tulis baca (Amin 1972).

\section{Aspek Hukum}

Sebagaimana dimaklumi, organisasi dan institusi politik yang diakui dan dipatuhi oleh masyarakat dalam sebuah daerah atau Negara mutlak harus ada, demi keberlangsungan hukum dan menjaga fungsinya sebagai pengikat bagi seluruh interaksi sosial dalam masyarakat tersebut yang harus dipatuhi secara bersama. Institusi atau organisasi tersebut selain berfungsi untuk membuat hukum dan peraturan yang tetap dan mengikat juga sebagai pengawal terhadap peraturan dan hukum yang ditetapkan dan disetujui secara bersama oleh anggota masyarakat tersebut demi kelangsungan hidup yang lebih aman, terjamin dan tenteram. 
Karena itulah ketiadaan institusi hukum yang berkuasa penuh atas masyarakat Mekah mengakibatkan ketiadaan sistem hukum yang dianut dan berlaku secara universal. Ketiadaan hukum ini tentu saja mengakibatkan ketiadaan peradilan tetap. Tapi meskipun demikian, tidak mesti lantas hukum pribadi berlaku pada masyarakat Mekah.

Dalam menyelesaikan persengketaan, biasanya hakim yang diangkat memutuskan berdasarkan sunnah atau tradisi yang sudah berlaku di kalangan mereka dan dianggap dapat diterima oleh seluruh masyarakat. Sistem sunnah sangat kental dalam masyarakat Mekah, dengan begitu dapat dipastikan bahwa seorang hakim yang ditunjuk adalah orang yang menguasai dengan baik sunnah-sunnah yang berlaku di kalangan mereka. Keputusan akhir hakim ini bukan saja menjadi keputusan untuk kedua belah klan yang bersengketa, akan tetapi juga akan menjadi acuan bagi mereka yang bersengketa pada kemudian hari. Dengan begitu posisi hakim ini bukan hanya sebagai pemutus perkara tapi juga merupakan penfasir terhadap hukum yang berlaku bagi masyarakat (Schacht 1971).

Pada periode Mekah ini, aspek hukum belum banyak tersentuh oleh dakwah Rasulullah SAW, karena pada fase ini dakwah lebih menitik beratkan pada masalah ketauhidan, sedangkan hal-hal yang berkaitan dengan berbagai hukum yang menyentuh setiap aspek kehidupan manusia belum banyak disentuh oleh wahyu keRasulan. Jadi hukum yang berlaku di kota Mekah masih banyak yang berasal dari tradisi bangsa Arab sendiri khusunya penduduk Mekah dan belum banyak berubah. Rasulullah SAW sendiri pada fase Mekah ini tidak bertindak sebagai hakim yang menyelesaikan setiap permasalahan dan persengketaan, kecuali ketika terjadinya perselisihan mengenai permasalahan peletakan hajar al-aswad.

Hal ini juga didasarkan pada kenyataan bahwa di kota Mekah keadaan Rasulullah SAW dan para pengikutnya termasuk kaum yang lemah dan tidak berpengaruh, meskipun setelah Islamnya Umar bin alKhattab dan Hamzah bin Abdul Muthalib, dua tokoh berpengaruh di kalangan penduduk kota Mekah, sehingga tidak dapat merubah hukum yang telah ada dengan menyesuaikannya sesuai dengan ajaran yang dibawa oleh Rasulullah SAW.

\section{Penutup}

Rasulullah saw. datang untuk menyebarkan sebuah tatanan baru kehidupan sosial pada masyarakat yang tidak mempunyai acuan dan norma-norma yang tetap selain dari tradisi yang terus berjalan di kalangan mereka. Sistem keluarga, fenomena-fenomena politis, 
ekonomi, sosial merupakan contoh dan bukti bagaimana masyarakat Mekah pada masa Rasulullah saw merupakan sebuah masyarakat yang hanya mempunyai tatanan sosial dan tatanan hukum yang hanya berdasarkan pada modifikasi hukum oleh aristokrat-aristokarat Mekah saja.

Perjuangan dakwah yang begitu keras dilakukan oleh Rasulullah SAW untuk merubah sistem dan stratifikasi sosial yang tidak berpihak kepada rakyat kecil dan kaum proletar dengan menyerukan semangat dan tindakan egaliterian hanya mendapatkan respon positif dari kalangan rakyat tertindas tersebut yang memang merasa diuntungkan dan mendapatkan keadilan di tengah-tengah masyarakat, namun tidak untuk kalangan para pembesar dan kaum aristokrasi yang selama ini mendapatkan keuntungan yang banyak dengan sebuah sistem yang telah lama berjalan di kota Mekah.

Usaha-usaha yang dilaksanakan oleh nabi Muhammad untuk membangun sebuah tatanan sosial yang baru berdasarkan prinsip keadilan dan kesetaraan status diantara manusia dan tatanan politik yang disebut dengan ummah yang memiliki sikap senasib sepenanggungan tidak berjalan dengan efektif. Usaha-usaha ini kemudian mengundang serangan balik dari para kalangan masyarakat Mekah, khususnya kalangan aristokrat. Pada akhirnya serangan gencar yang dilakukan oleh para penentang ajaran Rasulullah SAW memaksanya untuk pindah ketempat yang lebih kondusif demi kelangsungan agama dan risalah yang diperjuangkannya yakni ke Kota Madinah. 


\section{DAFTAR PUSTAKA}

Ali, K. A Study Of Islamaic History. Delhi: Idarah Adabiyat Delli, 1980.

al-Mubarak, Shafiyurrahman. Sirah Nabawiyah, terj. A. Mas'udi. Jakarta: Pustaka al-Kausar, 1997.

Amin, Ahmad. Dhuba al-Islam, Juz I. Kairo : Maktabah an-Nahdah, 1972. Fajr al-Islam. Kairo : Maktabah al-Nahdah, 1965.

Ashgar, Engineer Ali. The Original And Development Of Islam. New Delhi: Sangam Press, 1980.

Asy-Syarqoni, Abdurrahamn, Mubammad Sang Pembebas, terj. Ilyas Siraj. Yokyakarta: Pustaka Pelajar, 1998.

Azizi, A. Gaffar. Berpolitik Untuk. Agama, Misi Islam, Kristen dan Yahudi tentang Politik, terj. Ilyas Siraj. Yogyakarta : Pustaka Pelajar, 2000.

Brockelmann, Carl. History of The Islamic People. London : Routledge \& Kegan Paul, 1990.

Chaudhri, Abdul Ghafur. Mubammad The Educator of Mankind. Delhi : Adam Publisher \& Distributors, 1999.

Dahlan, Abdul Azis, et. al, Ensiklopedi Hukum Islam, jil. IV. Jakarta; Ichtiar Baru van Hoeven, 1999.

Esposito, John. L., Ensiklopedi Dunia Islam Modern, terj Eva, jil. IV. Mizan; Bandung, 2002.

H.M.H. Al-Hamid Al-Husaini, Riwayat Kebidupan Nabi Besar Mubammad s.a.w. Jakarta: Yayasan Al-Hamidy, 1995.

Haikal, Muhammad Husein, Sejarah Hidup Nabi Mubammad. Jakarta; Lintera Antar Nusa, 2003.

Hamka, Sejarab Umat Islam, Cet VII. Jakarta: Bulan Bintang, 1987.

Hasan, Hasan Ibrahim. Tarikh al-Islam, Jild I. Kairo: Maktabah alNahdah al-Misriyah, 1979.

Hodgson, Marshall. The Venture Of Islam. Chicago: Chichago University Press, 1974.

Issawi, Charles. Pilihan Dari Muqaddimah Bin Khaldun, Filasafat Islam Tentang Sejarah, Cet. II. Jakarta: PT. Tintamas, 1976.

Lapidus, Ira M. Sejarah Sosial Umat Islam, Bagian Kesatu dan Kedua, terj. Ghufron Masadi, A. Cet. I. Jakarta: PT. RajaGrafindo, 1999. 
A History Of Islamic Societies. Cambridge: Cambridge Universty Press, 1993.

Mubarak, Shafiyurrahman, Sirah Nabawiyah, terj. A. Mas'udi . Jakarta: Pustaka al-Kausar, 1997.

Mufrodi, Ali, Islam di Kawasan Kebudayaan Arab . Jakarta: Logos, 1997.

Mufrodi, Ali. Islam di Kawasan Kebudayaan Arab. Jakarta: Logos, 1997.

Nashir, Abdul, Polygami Ditinjau Dari Segi Agama, Sosial Dan Perundangundangan, terj. Chadijah. Jakarta; Bulan Bintang, 1976.

Philip K. Hitti, History of The Arabs. Lake Champlain, The New York Publisher, 1970.

Rachman, Budhy Munawwar. Islam Pluralis. Jakarta; Paramadina, 2001.

Schacht, Joseph, An Introduction To Islamic Law. Inggris: Oxford Press, 1971.

Shihab, M. Quraish. Wawasan Alquran, Tafsir Maudhu'i atas Pelbagai Pesoalan Umat. Bandung : Mizan, 2006.

Susanto, Musyrifah. Sejarah Islam Klasik, Perkembangan Ilmu Pengetabuan Islam. Jakarta: Prenada Media, 2003.

Syalabi, Ahmad. Islam DalamTimbangan, terj. Abu Laila. Bandung: Ma'arif, 1982.

Sejarah dan Kebudayaan Islam, terj.oleh Mukhtar Yahya dan M. Sanusi Latief. Jakarta: Mutiara Sumber Widya, 2000.

Tim Penyusun Ensiklopedi Islam, Ensiklopedi Islam, Jild V, cet. Ke-IX. PT Ichtiar Baru van Hoeve, Jakarta: 2001.

www.badilag.net,

www.geocities.com

www.mediaisnet.org

Yatim, Badri. Sejarah Peradaban Islam, Dirasah Islamiyah II. Jakarta: PT. RajaGrafindo, 2002.

Yunus, Mahmud. Sejarah Pendidikan Islam. Jakarta: Bulan Bintang, 1996. 